\title{
Dayak Meratus Charm Festival as a Learning Resource of Social Sciences Education
}

\author{
Herry Porda Nugroho Putro \\ Department of History Education Faculty \\ of Teacher Training and Education \\ Universitas Lambung Mangkurat \\ Banjarmasin, Indonesia \\ pordabanjar@gmail.com
}

\begin{abstract}
Social science education has the goal of preparing students to be good citizens. The subject of social science learning is social and cultural life. Indonesia is a multicultural country; every region has culture and tradition. Modernization and development of science have influenced the existence of regional culture. The Dayak Meratus community in Halong, South Kalimantan, has had much influence from modernization and science, as well as the influence of the external environment. Every year the Dayak Meratus people in Halong hold an event called Dayak Meratus Charm. The research problem is about the purpose of the celebration event of the Dayak Meratus, the event of the Dayak charm of Meratus, the event of the Dayak charm of Meratus as the source of learning social science. The data in this research is obtained from observation, interview and documentation from internit. A conceptual model of integration in social science learning is through interviews with social science teachers and curriculum documents. The result of the research is that the event of Dayak charm Meratus aims internally for the inheritance of tradition, improving the economy of society, making the charm of Dayak Meratus become the annual tourist agenda in South Kalimantan. Externally is introducing the culture of Dayak Meratus, and attract tourists. The agenda of martial arts celebration event is a form of ritual, dance, traditional game, culinary, exhibition of woven products. The event of martial arts celebrating can be integrated into the subject of environment, society, and culture. The learning model is cooperative with the drawings. Learning activeness with research recommendation, a celebration of mercurial Dayak charm can be used as a source of social science learning for all regions in Indonesia.
\end{abstract}

\section{Keywords-Dayak Meratus, culture, Dayak charm}

\section{INTRODUCTION}

Indonesia is a country that has thousands of islands and various ethnic groups. Each island has its own culture, so in Indonesia, there are various cultures. The culture of every tribe still looks like ceremony, dance, traditional food, clothes, language, art, and necessities of life.

South Kalimantan has a dominant culture, Banjar, and Dayak. Banjar and Dayak culture are still visible in life activities. Banjar culture side by side with Dayak culture. Banjar culture can be found almost in most places in South
Kalimantan such as Banjarmasin, or regency towns such as houses, food, clothing, language, arts, social, river transportation, and religion. Banjar culture is better known to the people than the Dayak Culture.

Dayak culture is less visible to people in South Kalimantan. Dayak culture can be seen in areas far from the city, in Dayak settlements. Dayak settlements are scattered in rural areas and mountainous terraces. Their livelihood is mostly as farmers. Dayak culture is associated with honoring ancestors and planting.

Halong is located in Balangan district of South Kalimantan is a Dayak settlement, the Dayak Meratus. Halong people annually organize a festival of "Dayak Meratus Charm", at this event performed Dayak art and tradition about Dayak rituals, dances, games, clothes, and food. Dayak Meratus Charm Festival is witnessed by all people from outside Halong or South Kalimantan.

Social Science Education is education about society and culture. Students learn about society and culture from every region and world, so that students can have values and be ready in life. Students can grow their character and have knowledge about society and culture.

This study discusses the purpose and activity of the festival of Dayak charm Meratus in Kapul Village, Halong. Dayak charm festival Meratus as a learning resource for social science education.

\section{METHODS}

\section{A. Areas of Study and Data Collection}

The research location is Kapul Village, Halong District Balangan Regency, South Kalimantan. This village where the festival held a charm of Dayak Meratus, the residence of Halong Dayak tribe. At the festival site, there is a Dayak traditional house, art studio, exhibition venue, games for traditional games, for mass dance, for chopsticks. The distance of Halong District to the district capital is $12 \mathrm{~km}$. 


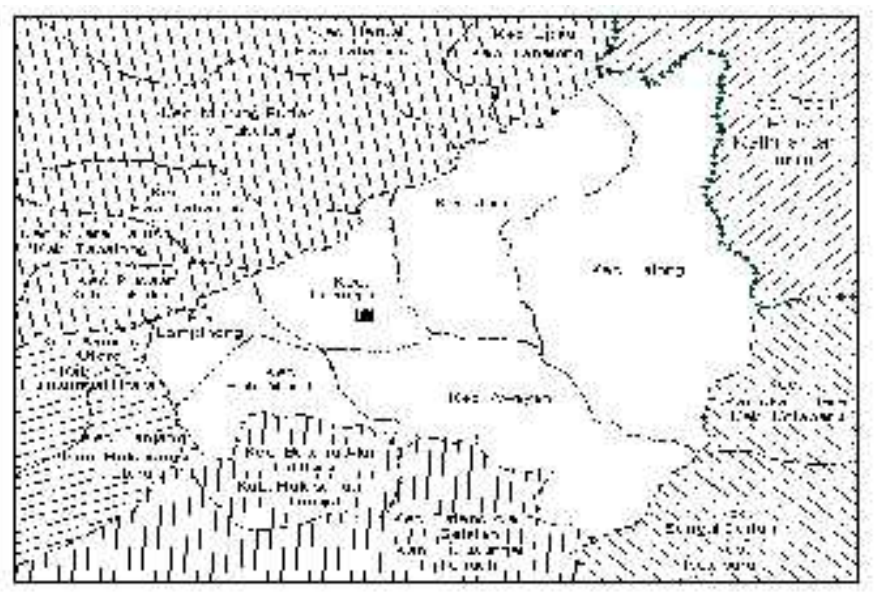

Fig 1. Map of Halong District

The research method used is qualitative research method. Data were collected through observation, interviews, documentation. The research location is Halong Village of Balangan Regency of South Kalimantan. In the art studio, observation of festival activities and interviews with some traditional figures, this place is the center of activity, preparation, and eating together.

Observation data from field observations at the Dayak festival of Meratus festival, March 3, 2017. Observations were made in the community, houses, festival participants, and performances. Observational data on learning resources were conducted in the classroom using the materials of the Dayak festival of Meratus. Interview data from Village Head, Customary Chief, Community, and teacher. The document in this study is a photo of activities during the event took place in Halong and in classroom learning activities. Data analysis with the qualitative analysis was done simultaneously, classification, coding, identification, categorical, review, and chronological [1].

\section{RESUlt AND DisCUSSION}

Dayak Meratus Charm Festival has been held annually in Kabul Village, Halong District. Participants of the festival are representatives of Dayak tribe originating from the mountainous slopes of Meratus in South Kalimantan, such as Hulu Sungai Selatan, Hulu Sungai Utara, Hulu Sungai Tengah, Balangan, Tanjung. They display their cultural riches, such as Dayak clothing, wicker, Dayak food, Dayak dance, Dayak games, musical instruments.

\section{A. Festival Location}

Kapul Village is one of the villages in Halong District. Halong Sub-district is interesting because it is designated as Traditional Settlement based on SK Bupati Balangan Tahun 2010. The traditional settlement is Halong Halong community with $55.75 \%$ of Halong Subdistrict, consists of ten villages, Binuang Santang Village, Marajai Village, Mauya Village, Mantuyan Village, Tabuan Village, Buntu Pilanduk Village, Kapul Village, Ha 'uwai Village, Liyu Village and Aniungan Village [2]. Kapul village is the center of arts and cultural activities, in this village, there is a place of Dayak art activities, Wadian Tambai Cultural Arts Studio. The dancing and singing exercises are performed by Halong Dayak youths every afternoon in this studio. Musical instruments are also available in this studio.
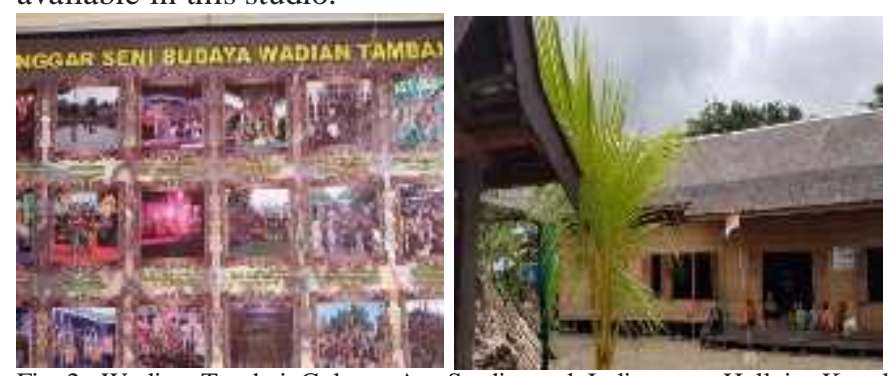

Fig 2. Wadian Tambai Culture Art Studio and Indigenous Hall in Kapul Village

Indigenous Dayak Hall is a longhouse located in Kapul village, about $50 \mathrm{~m}$ long. Longhouse in the Dayak community there is up to $200 \mathrm{~m}$. In the longhouse lived some families. The wood used is Ulin wood, the roof of the house of shingle or leaf of rumbia, the walls of the house of the board, the wooden floor of Ironwood, on the original longhouse distance with high ground $1-5 \mathrm{~m}$, at the bottom of the place for livestock. The location of a high house, to avoid floods, wild animals. This traditional hall is always used for traditional Dayak ceremonies, where the Dayak Meratus people live from various places, customary meeting places, places of ceremonial objects. Long Dayak house is called lamin / Betang

Kapul village is strategically located, surrounded by people's homes as traditional settlements. This location is close to other villages which are multicultural, because there are several religions, namely: Islam, Buddhism, Hinduism, Protestantism, Catholicism. Temple places like temples, monasteries, churches, mosques, and traditional Dayak halls are located in traditional residential areas. Community mutual respect and cooperation on every commemoration of religious holidays. The form of mutual respect is a ritual on the aruh event, the meat that is sacrificed is a buffalo or a goat, not a cow or a pig. At the location of research also found various tribes, such as Dayak, Java, Sunda, Batak, Bugis, they live harmonious and mutual respect. Halong Sub-district can be a miniature Indonesia.

Adherents of religion in Halong District occupy their respective villages, for example, Buddhist there are many in Kapul Village, Hindus are found in Liyu Village, there are many Moslems in Halong, Christian, and Catholic villages found in several villages. Buddhist worship venue, Damasekha Hindu Buddhist temple, Jaganatha Berinin Jaya temple is located in Halong. Cooperation and mutual cooperation between religions is seen in every event are and house construction [3]. 


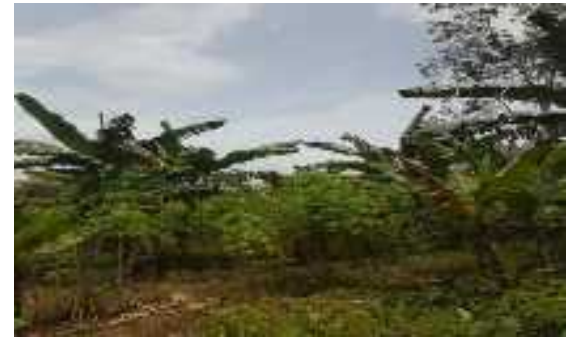

Fig 3. Gardens in Kapul Halong Village

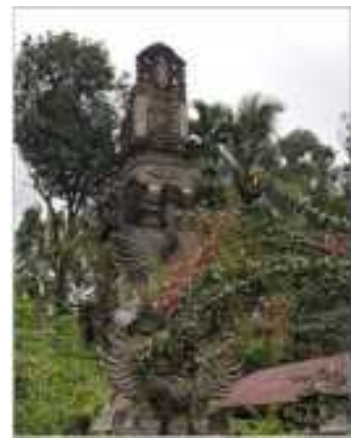

Fig 4. Temple on Halong Kematan

\section{B. Dayak Meratus Charm Festival}

Dayak Meratus charm is an annual event, a series of anniversary events of Balangan Regency. The event was held in March. The purpose of this event is a medium of inheritance and the introduction of all Dayak Meratus culture. Halong people, especially the younger generation, can be more familiar with and continue to practice Dayak Meratus tradition and Dayak Meratus culture. The development of informatics and technology should not reduce the understanding and love of culture and tradition. The Dayak tribe Meratus Halong judge, some of the children next generation is no longer and less familiar with local customs and wisdom of Dayak Meratus tribe. "Ngentan adat leluhur amak nyambelum banua " (lifting adat leluluhur to revive the village). Dayak cultural heritage to the younger generation is done with stories, songs, music, dances containing heroism and ethics [4].

Dayak Meratus charm also shows the beauty and richness of the Dayak Meratus culture, so as to develop a sense of love in their own culture. Variety of activities of Dayak culture are displayed, so as to attract outsiders to come to Halong. The charm of Dayak Meratus can be a tourist destination, so that the result of Halong cultural culture can be known more widely, and can increase people's income. The Dayak Meratus Daydreams are Silahturahmi Indigenous Dayak Council throughout South Kalimantan and traditional figures, traditional balogo games, traditional bagasing games, mutuu (pounding rice), chopsticks, traditional kenjee (enggrang) games, traditional Dayak festivals, Gentur Bersama dance, KDI artist, climbing manan, fire bath. Activity schedule in the figure:

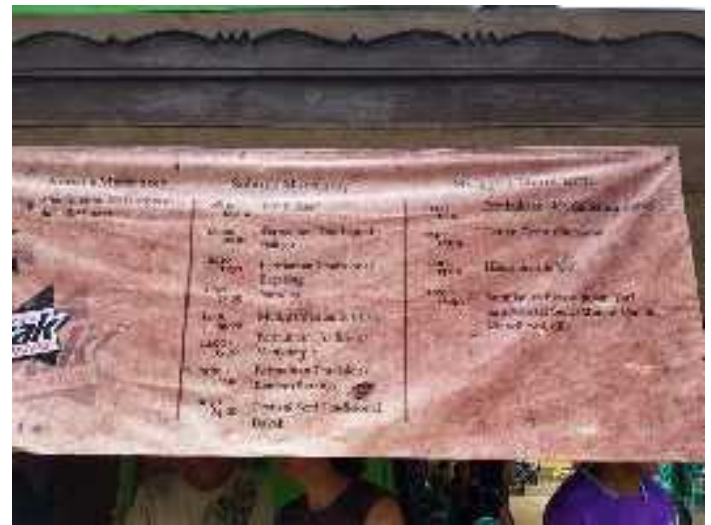

Fig 5. The Day of Meratus Day 2017 Banner of Activity

Meratus Adat Enchantment event can reestablish the existence of Culture. Dayak Meratus, although there are still shortages. Obstacles, less extensive land, visitors coming from Balangan and Outside the city quite a lot. Each event shows that the Dayak Meratus community can survive and be able to master nature, all cultural completeness comes from nature, for example, chopsticks used for hunting, clothing from bark or animal skins. Medication skills (batatamba), that all diseases can be treated.

\section{Dayak Meratus Halong Clothes}

At Dayak Meratus Pesona event also held a community craft exhibition, in the form of wicker from rattan, making necklaces from beads. Dayak traditional clothing exhibition of bark and ornament on Dayak clothing.

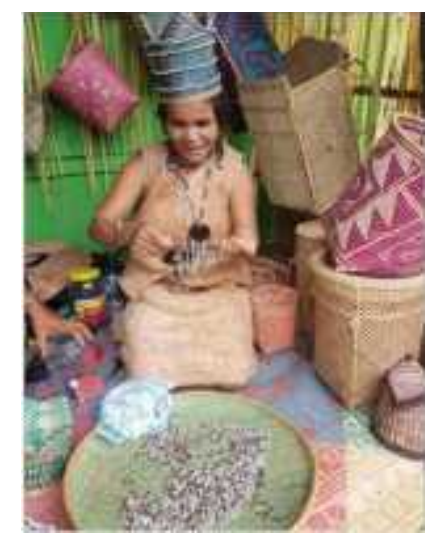

Fig 6. Leather clothing, beaded crafts, woven rattan 


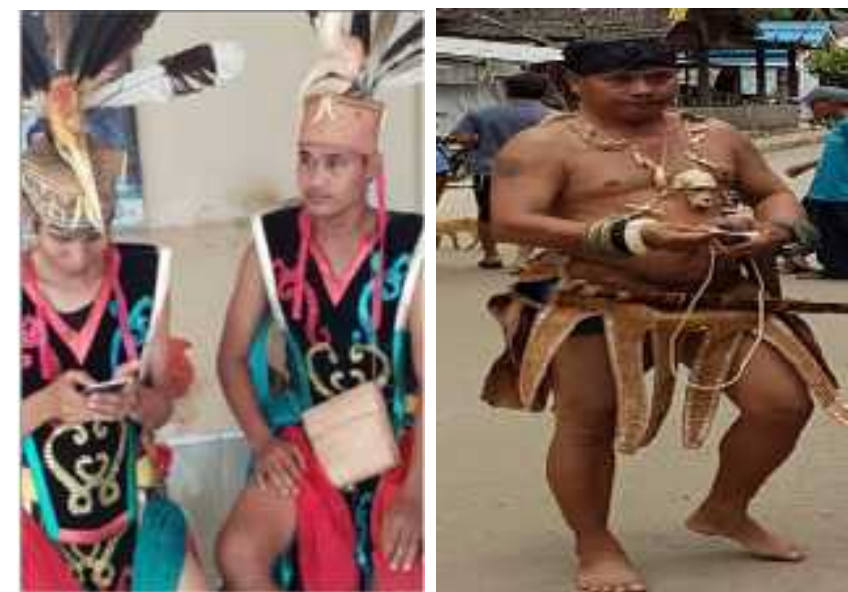

Fig 7. Dayak Meratus Halong Apparel and Ornament, chiseled from the woodcut

The original clothes of the Dayak tribe of the bark, the tree whose skin is used is the tree erau, siren, nyamu, tengang, lonok, and so on. Clothes Dayak tribe has a function as a cover body. Dayak men used strips, bark or cloth wrapped around the waist, front and back worn by men. At the top use of a beaded bead carvings and wearing a loincloth. This outfit is equipped with a mandau (a typical Dayak sword) tied at the waist, at the top using a beaded bead carvings and wearing a loincloth. Dayak tribe likes with beads, bird feathers as decoration. Dayak traditional dress shows that Dayak people like to work, always want to develop themselves[5].

The Dayak community also recognizes the technique of weaving to make clothes. The yarn fiber is produced from the bark of the tree. The base color, as well as the strong and clay, is light brown. To obtain black or red heart (which is the dominant color of traditional Dayak weavings), immersed in an aqueous solution mixed with tree sap.

\section{Dance Show}

At the Dayak Meratus Charm showcased various arts, one of which is dance. The art of dance in the Dayak community is related to ceremonial activities or rituals and offerings. Almost every show is always dancing. Dayak tribe, old, young, male, female likes to dance, there are approximately 48 dances, such as dance to greet guests, dance at the rice harvesting ceremony, the dance of war, dance at the ceremony Tiwah, social dance [5]. Wallaca, A. recounts that when he arrived at the Dayak Bukit area was greeted with dance by the Dayak tribe [6]. Dancing is the hallmark of most Dayak tribes, they form circles while dancing and spinning [7]. At Dayak Dayak Meratus Dayak dance show performed only partially, among others dance repulsive reinforcements, dance bending, dance for rice planting ceremonies, dances in rituals. Members of the dancers are women, wearing Dayak dance outfits. Dances for ritual performed by women and women followed by Balian. Attributes commonly used Balian by marking certain body parts with writing that serves as an identifier to contact the spirits. Balian wears a sung (or headgear), wears a beaded necklace, animal fangs, and a small statue, wears a long cloth (tapeh). At the waist was wrapped a long cloth decorated at the end. On the wrist wears a bracelet that serves as a musical accompaniment in the ceremony and as a means to facilitate rapport with the spirits.

Mutuu (pounding rice) is usually in the form of dance tremble, symbolizes the woman is pounding wooden rice symbolizes the pounder while the grains symbolize the grain of rice. This dance is often shown to receive guests. At Dayak Meratus Charm pounding rice displayed 3-4 women, sometimes heard the sound of dimples. The Dayak Meratus people always maintain a balance with nature, a form of gratitude towards nature done with ceremonies. Ceremonies and dances, held after harvest or before planting rice. This belief shows that the Dayak community has values, rules, and laws about the environment.

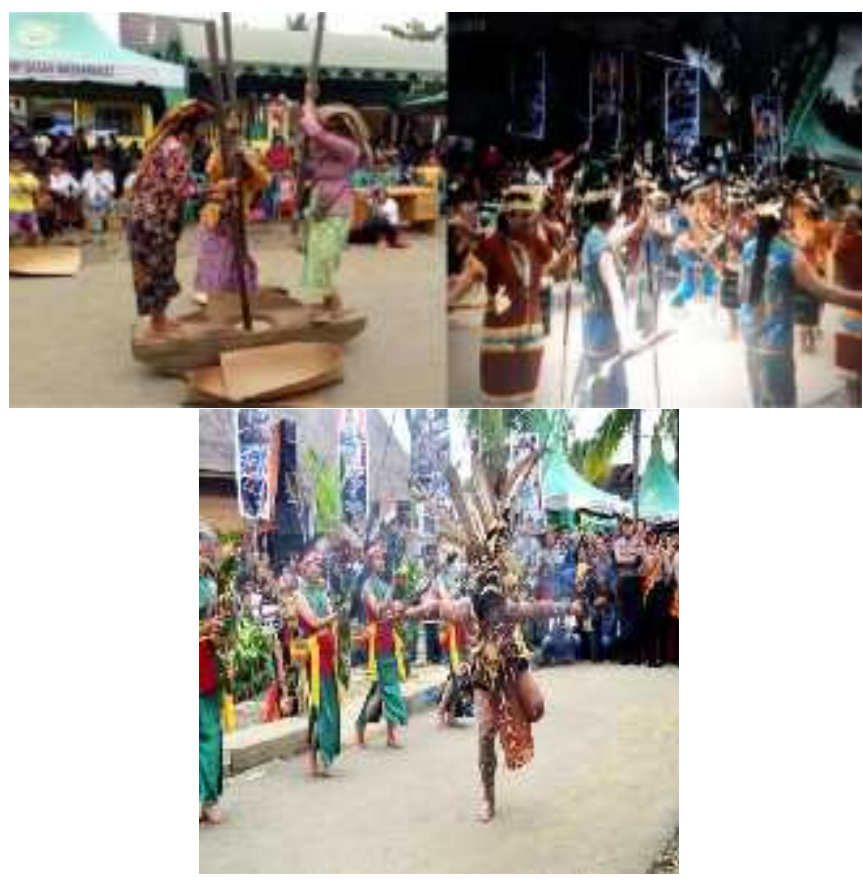

Fig 8. Mutuu (pounding rice), Dancing rice, and Dances Reject Bal

\section{E. Webbing}

Webbing is an art that the Dayak community deals with handicrafts for the necessities of life, such as equipment for farming, cooking supplies, hunting, fishing. The material used is of rattan or bamboo. In woven bags, baskets, baskets or mats are colored and the images that contain the meaning of life. Dayak Meratus people have been able to make various webbing that is useful for everyday activities, we often encounter baskets or baskets brought to the fields.

Each webbing has motifs that describe the natural environment. Suppose describes the plants that are around him, the animals around him. The woven motif is also adapted to the use of the webbing. 


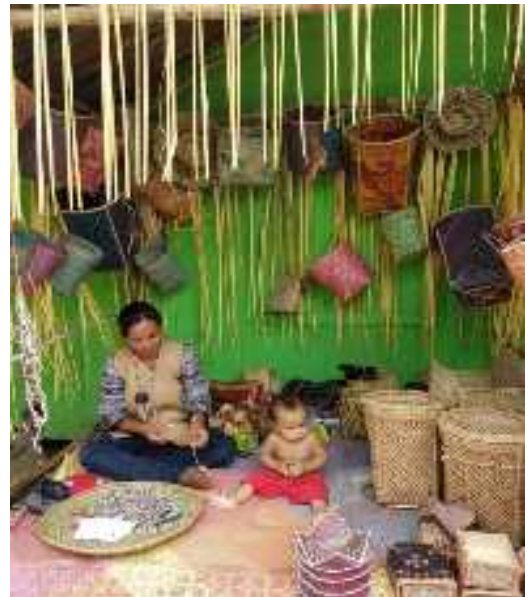

Fig 9. Woven Dayak Meratus Community

\section{F. Traditional game}

Dayak Meratus charm also features some traditional Dayak Meratus play, bagasing, balogo, mutuu (pounding rice), kenjee (engrang), chopsticks, climbing standing trees. According to Rutter, O. The traditional game of the Dayak community is traditionally performed every year, people close to the river hold boat races, swimming competitions, catching ducks. Sging is a race by firing five supit boys within thirty seconds, wearing a spear with a spear in a supit pipe, a supit child taken from its container on the back, taking a deep breath and blowing hard through the mouth of the chopsticks. Competition contest shows that the Dayaks are capable of making weapons for hunting, skill, earnestness, and cooperation [7].

Bagasing, balogo, kenjee are traditional games the same as anywhere else. Bagasing is made of strong, oval-shaped wood, then thrown with a rope, its winner is the longest spin. using materials from flat and flat coconut shells, the game is done by two people shooting each other coconut shell by using a small stick. Kengjee is known for enggrang, this children's game using long wood, about $30 \mathrm{Cm}$ from the bottom is buffered like a shoe, the participant running faster is the winner.

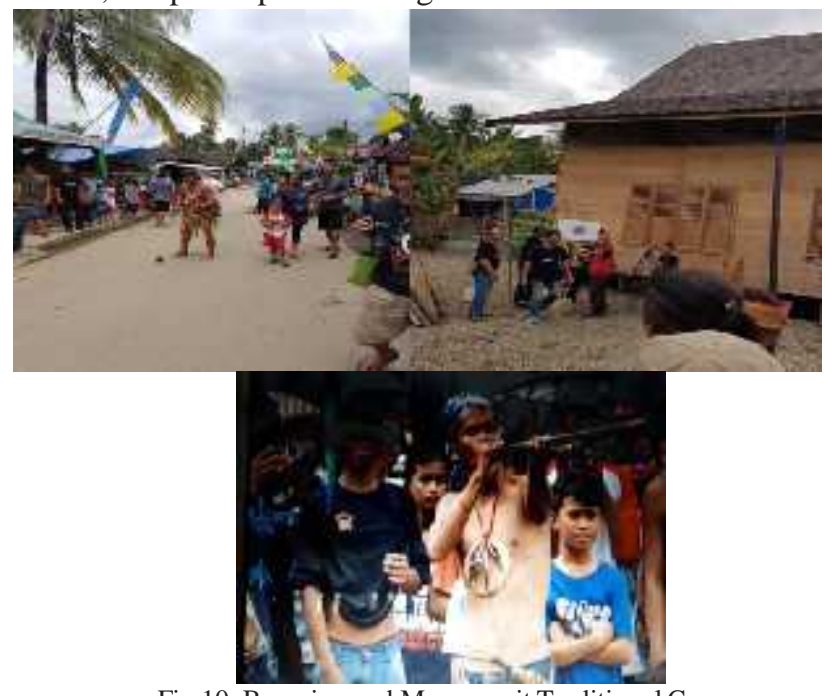

Fig 10. Bagasing and Manyumpit Traditional Games

\section{G. Dayak Meratus Charm In Social Science Education}

Dayak Meratus Charm Festival in education is a multicultural education. The Dayak culture at the event of Dayak Meratus displayed, students can learn about the elements of culture by taking the example of Dayak culture. Students can recognize and take value from Dayak culture, for example, arts, livelihood, language, religion, social system, living equipment.

Multicultural education is education that integrates ethnic and cultural diversity in education. Multicultural education is an educational strategy using cultural differences (ethnicity, religion, language, social class, race, gender) to achieve educational goals. Multicultural education to build the character of democratic, humanist, and pluralist students [8]. Education is related to culture, cultural differences are very sensitive, in the learning of multicultural education can help students develop pride in cultural heritage, in education all students should be able to understand, appreciate, and contribute to all cultures [9]. The purpose of Multicultural Education: to help students understand their culture, to invite students to learn about other cultures, that culture has to mean, students can learn various cultural results, reduce discrimination and minority flavor of one group, culture can build skills through local wisdom [10].

Social science education is education about social life, the material delivered comes from around the students to about the world. Social science education aims to prepare students for a better quality of life so that students can play an active role and contribute to society as a nation. This can be seen in the development of teaching models and subject matter from students' immediate environments to the sphere of the world.

...by following the holistic and coordinated approach to study of men living in societies, we design our program as follows: The sequence of themes or emphases is drawn from the fact that each of us lives within a system or set of expanding communities that start with the oldest, smallest, and most crucial community-the family placed in the center of the concentric circles-and progresses outward in everwidening bands through the child's neighborhood community; the child's local communities of city, country, and/or metropolis...[11].

South Kalimantan is a province with a population of multiethnic, namely: Banjar, Dayak, Java, Bugis, Sundanese, Batak, Madura. Ethnic origin is Banjar and Dayak. Ethnic Java is also quite large in South Kalimantan. Any place in South Kalimantan can be found in these ethnic groups.

In Social Science education there are subjects on Ethnic and Cultural Diversity. The subjects taught are ethnic diversity, ethnic identity, ethnic traits that have cultural similarities, fundamental features that distinguish each ethnic. Students learn that in Indonesia there are 1,128 ethnic groups, each tribe has differences. Students learn about the results of Indonesian culture in the form of dance, song, and work. Dayak Meratus charm can be a source of learning about the 
culture, students learn that Dayak Culture is different from other tribes in Indonesia. Students can learn about a culture by looking at Dayak culture. Students can discuss and understand cultural values. Through Merakus Dayak Pesona students can see that Dayak Meratus tribe has the skills to cultivate forests and environment, cooperation, strong belief, local wisdom, adaptive, tenacious, and honest.

Dayak Meratus charm can also be a learning material of social science about the dynamics of a population of Indonesia, namely: population distribution, population growth, and population quality. Students learn that the Indonesian population consists of various ethnicities spread in various places in Indonesia.

Dayak Meratus charm can be a learning material of social science about social interaction and social institution. At the Dayak Meratus Charm social interaction is very visible, students can see all walks of life involved in the event. All actors of culture interact and respect each other. Students can learn about the existing social institutions in the Dayak Meratus tribe by looking at Dayak Meratus Charm, for example, family institutions, customary institutions, religious institutions, economic institutions.

The village of Kapul where the celebration of the Dayak Meratus charm can be a learning material for social science about the village, namely: the characteristics of the village, the village community, agriculture, culture. Various religions and tribes in Kapul village can be a subject of Social Science about social interaction, diversity of people, social solidarity, and multicultural in the countryside.

The activity in multicultural education is to look at indigenous peoples and compare them on TV shows, to learn about the ethnicity around students: the hallmark of names and culture, identify ethnic roles and achievements in the community, inquire about the ethnic history with the help of parents or grandfathers, grandmother, watching cultural references from each ethnic group, reading books about ethnic group members' character, performing dramas or games from dolls about various ethnic groups, visiting museums featuring exhibitions about ethnic groups; and designing a class museum about the culture of an ethnic group, inviting ethnic groups into the class [12].

The Dayak Meratus Enchantment event in Social Science lessons is used to understand indigenous peoples around the students, ie Dayak tribe, understand the Dayak characters and culture, understand about the works and art of indigenous Dayak people. In Social Science lessons, teachers can construct questions about: (1) What does "life" mean when used in this way? What is a "society:? Then the students gave a response about the Dayak community, by watching a picture or video about the Dayak Meratus Charm event. (2) The documents and pictures of the Dayak Meratus Pesona event are used as materials to discover indigenous ideas and life (Dayak). Students write and tell about the Dayak Meratus community, searching for new ideas by looking for new data about Dayak people. The Dayak Meratus Charm event can be used to develop thinking skills by reflecting on the proceeding investigation ... put the scientific method to work to resolve a problem! You have a question of how to make a decision to generate your own answer [13].

Dayak Meratus Charm Festival can be used as learning materials in the form of artifact collection, easy food recipes, arts, and crafts, song and dances, maps, community history, current events, inquiry, scrapbook contributions, need a chart, analyze children's newspaper [14].

\section{CONCLUSION}

Dayak Meratus Charm Festival is an event to introduce to the young generation about Dayak culture, especially Dayak Meratus. This event is held as a cultural heritage because young people are less interested in regional culture. At this event all visitors are involved in activities, dance together, eat together, play together. Meratus Dayau Charm Festival contains values of togetherness and openness of indigenous peoples in the era of globalization. Meratus Dayau Charm Festival can improve the economy of rural communities as a tourist area.

Dayak Meratus Charm Festival can be a learning material of Social Science about culture, customs, social interaction, the village community, cultural diversity. Learning strategies are thinking skills with the inquiry, students observing and developing ideas through pictures, videos, dancing of Dayak Meratus dance.

\section{ACKNOWLEDGMENT}

The research was funded by Lambung Mangkurat University. The author would like to thank the fund for his research.

\section{REFERENCES}

[1] J.W. Creswell, Research Design: Qualitative, Quantitative, and MixedMethods Approaches, Third Edition, California: Sage Publications, 2010

[2] H.M. Efrani, Pemukiman Tradisional Dayak halong, https://efrani.wordpress.com/2011/01/01/ permukiman - tradisionaldayak-halong, [on-line18/10/2017], 2011

[3] Wahyudi, Mengunjungi Miniatur Indonesia, Kecamatan Halong Kabupaten Balangan, http://www.humasbalangankab.com/2016/01/ miniatur-indonesia-umat-lima-agama.html?m=0, [on-line, 19/10/2017], 2012

[4] N.P. Porda, M.Z. Anis, and Mansyur, The Lost City: Menelusuri Jejak Nyai Undang dari Kuta Bataguh Dalam Memori Suku Dayak Ngaju, Yogyakarta: Ombak, 2017

[5] T. Riwut, Kalimantan Membangun Alam dan Kebudayaan, Nila, R., Husein, A. F.(penyunting), Yogya: Tiara Wacana, 1993

[6] A. Wallaca, Kisah Petualangan Terbaik Abad Ke-19 Menjelajah Alam Borneo, Malay Archipelago, Anna Karina (translate), Surabaya: Stomata, 2017

[7] O. Rutter, Sejarah Kalimantan, Yogyakarta: Indoliterasi, 2017

[8] P.J, Farris, Elementary and Middle School Social Studies: An Interdisciplinary, Multicultural Approach,Illinois: Waveland Press, Inc., 2012

[9] G.W. Maxim, Dynamic Social Studies for Constructivist Classroom: Inspiring Tomorrow's Social Scientists, Boston: Allyn \& Bacon, 2010

[10] F.J.A., Bank, Multiethnic Education: Theory and Practice, Boston: Allyn \& Bascon, Inc,, 1988 
[11] P.Hanna, "Revising The Social Studies: What is Need?,"Herbert, L.J., Murphy, W, Structure in the Social Studies, Social Studies Reading Number 3, p. 28, Washington: NCSS, 1968

[12] F. Stopsky, S.Lee, Social Studies in a Global Society, New York: Delmar Publisher Inc, 1994, p.433.

[13] B.K. Beyer, Teaching Thinking in Social Studies Using Inquiry in the Classroom, Ohio: Charles E. Merril Publishing Company, 1979, p.33.
[14] D. W. V. Cleaf, Action In Elementary Social Studies, Boston: Allyn and Bascon, 1991, p.337-338. 